\title{
A critical review of the effects of fluid dynamics on graphene growth in atmospheric pressure chemical vapor deposition - CORRIGENDUM
}

\author{
Fatin Bazilah Fauzi, Edhuan Ismail, Mohd Hanafi Ani, Syed Noh Syed Abu Bakar, \\ Mohd Ambri Mohamed, Burhanuddin Yeop Majlis, Muhamad Faiz Md Din, and Mohd Asyadi Azam \\ Mohd Abid
}

doi: https://doi.org/10.1557/jmr.2018.39, Published by Cambridge University Press, 8 March 2018

In Fauzi et al. ${ }^{1}$, references 84 and 85 were cited incorrectly. The correct references are as follows:

84. C.F. Bonilla, R.D. Brooks, and P.L.J. Walker: The viscosity of steam and of nitrogen at atmospheric pressure and high temperatures. Proceedings of General Heat-Transfer Discussions (Institution of Mechanical Engineers, London, 1951); pp. 167.

85. H.J.M. Hanley, H. Intemann, and R.D. Mccarty: The viscosity and thermal conductivity of dilute gaseous hydrogen from 15 to 5000 K. J. Res. Natl. Inst. Stan. 74A, 3 (1969).

The authors apologize for these errors.

\section{REFERENCE}

1. F.B. Fauzi, E. Ismail, M.H. Ani, S.N.S.A Bakar, M.A. Mohamed, B.Y. Majlis, M.F. M. Din, and M.A.A.M. Abid: A critical review of the effects of fluid dynamics on graphene growth in atmospheric pressure chemical vapor deposition. J. Mater. Res. doi:10.1557/ jmr.2018.39, 1-21 (2018). 